\title{
Humour as resistance: Disaster humour in post-9/11 United States
}

\author{
Aju Basil James \\ Department of English, University of Hyderabad, India
}

\begin{abstract}
This paper studies the evolution of political humour in media in the United States after 9/11. Previous research has identified patterns in the evolution of jokes on the Internet but a study of patterns of humour in mainstream media remain scarce. This paper looks at late night television shows and cartoon strips in post-9/11 United States, and tries to plot a pattern in their evolution. Television programs such as The Daily Show or cartoon strips such as The Boondocks and Get Your War On have become major sources of political news, especially for the younger section of the population. These media constitute and react to the business of political news in the United States. This paper attempts to explore what political consciousness is constructed through humour in these media. Any pattern that may emerge out of this study is also reflective of humour's engagement with politics, especially in a time in which irony was declared to be dead. A comparison of humour on these different fora throws some light on how the United States reacted to 9/11 through humour as well as what material, political or psychological forces drive humour on different kinds of media.
\end{abstract}

Keywords: disaster humour; post-9/11 humour; political humour; The Boondocks; Get Your War On.

\section{Introduction}

Making jokes about accidents and catastrophes and making fun of the forces of death and destruction is a peculiar phenomenon. Disaster humour, as it is widely known, is a curious juxtaposition of humour and tragedy. Disaster humour has had a long and varied life, ever present in human civilisations through folk songs, tales and jokes. However, disaster jokes as we know them today, in their set format and wide circulation, is a recent phenomenon. Christie Davies argues that disaster jokes were spurred by the rise of television in the 
twentieth century. The incongruous package of television, which combined soaps, reality shows and advertisements with news, turned out to be perfect fodder for jokes based on tragic events across the globe. The shock and awe that television news sought to create, along with a hegemony of feeling that told viewers how to react to disasters encouraged the growth of disaster jokes (Davies 2003: 26).

The proliferation of disaster jokes continued well into the twenty first century. The terrorist attacks of September 11 spawned an immense number of disaster jokes all over the world. In the aftermath of a tragedy of cinematic nature, disaster jokes exploded across the Internet. However, a humorous approach to the terrorist attacks and its aftermath was not limited to Internet groups or forums. Very soon, the post-9/11 political and cultural scenario was being addressed through humour on mainstream media as well, in late night television shows, stand-up comedy concerts and cartoons.

This paper looks at two cartoon strips - The Boondocks and Get Your War On- as sources of early post-9/11 humour. These cartoons provide largely textual representations of the predominant political mood and atmosphere of that time as well as creative approaches to understanding America and the world.

The Boondocks, written by Aaron McGruder, is a comic strip that later made the shift to an animated television show on the Adult Swim network. Boasting of a loyal community, The Boondocks is particularly well known for its controversial take on black culture and politics. However, while many strips and shows successfully exploit the cultural and communal affinity of its audience, The Boondocks has largely taken the path of courting controversy through its political stance. While it is unabashedly "black" in its outlook, this position is not its primary or sole argument. Rather, The Boondocks is known for what some have called political propaganda that transcends community loyalties and operates on a national level. It is a stringent critic of George W. Bush and Bush era policies such as the Iraq war and the increased pervasive powers of the state. Its position on these and many other political issues is a blend of the black political voice and a liberal, satirical commentary. Thus, it is possible to critically look at The Boondocks in comparison to texts whose readers are not usually described with reference to racial or communal identities. The Boondocks should be especially noted for the way in which it engages with its audience. The Boondocks forums across many platforms are abuzz with the hot political topics of the day and are as much a space for political commentary as the cartoon. The Boondocks thus stands as a great example of how humour can open up alternative spaces of political engagement.

Get Your War On, the second comic strip analysed in this paper, provides political commentary in the form of scathing sarcasm and irony. Get Your War On, written by David Rees, tries to be a conversation on politics. It thrives on a heady play of language, keeping with the contemporary age of media saturated politics. Get Your War On features a corporate world, largely insulated from the effects of America's adventures abroad, where employees discuss the politics of the day. It is a brash and unapologetic take-down of the high-handed and hypocritical moves of the Bush administration.

One of the first scholarly works that dealt with disaster humour was Elliot Oring's "Jokes and the Discourse on Disaster". In this essay, Oring analyses the jokes that followed the 1986 Challenger shuttle disaster in relation to the conventions of public discourse that surrounded the event. This essay provided a framework to understand disaster humour as the product, and production, of certain discourses. Further, this framework took disaster humour beyond the domain of psychological analysis into an analysis that situates disaster humour in political, ethical and ideological dimensions. They often push against social conventions of 
decency and "speakability" and challenge these norms in media narratives of disasters (Oring 1987: 282).

The humour this paper deals with can be considered disaster humour owing to its similarity in origin to what has been conventionally marked under that category. The humour that appears in the media examined here are often inspired or precipitated by the media coverage of events, related to the September 11 disaster and the political events that followed it, on television. They differ from the disaster jokes that circulated on the Internet in that they do not directly use images prominently associated with the disaster, but nevertheless maintain the centrality of the disastrous event. More often than not, it is a commentary on television news, in addition to the events themselves. This paper argues that humour pushed the boundaries of "speakability" that was set by mainstream media in constructing the discourse on $9 / 11$ and the government's response to it. As a reaction to the nature of television coverage, humour advocates a rethinking of the ideological positions taken by mainstream media houses by parodying them or engaging with the discourse through irony and sarcasm. It is a response to what Davies called "secular preaching" and it is the characteristics of short jokes that are commonly referred to as disaster humour as well. While the jokes in the media considered in this paper are different in form from those posted by anonymous users on the Internet, they are similar in origin and performance. Therefore, the humour presented through these media could be considered disaster humour and studied as such.

Any study of disaster humour should start with Bill Ellis' study of joke cycles. Ellis found that disaster jokes, which circulated orally and on the Internet, appeared in waves, with certain characteristics attached to each wave that could reflect the discourse on these events (Ellis 1991: 117; 2003: 78). Ellis' analyses of joke cycles after the Challenger disaster of 1986 and September 11 deal largely with expressions in the private sphere; the jokes are mostly unmediated reactions to mediated news. This thesis attempts to draw a pattern in the use of comedy, irony and satire in the public sphere, on mediated channels, and aims to study the nature of the sequence of political humour. As an integral part of the public sphere, humour on television, in cartoon strips and stand-up comedy is mediated and often designed to express a certain ideological position. This paper attempts to draw a pattern in the use of comedy, irony and satire on mediated channels and aims to study the nature of political humour, within the framework of disaster humour.

Paul Lewis, in his book Cracking Up: American Humor in a Time of Conflict, critically examines the nature of comedy in the popular and political realms. He questions the place of comedy in a time as turbulent as the post-9/11 decade and examines the various roles it plays. Lewis' book is an attempt to understand the relevance of humour in a time when many commentators declared that irony is dead, and if not, killed.

One of most definitive works on post-9/11 humour was the anthology, A Decade of Dark Humor: How Comedy, Irony and Satire Shaped Post-9/11 America, edited by Viveca Greene and Ted Gournelos. These essays operate on the basis that humour has an important role to play in the political sphere and the media. The anthology sees post-9/11 political humour as scripting a counter-narrative to the official discourse. It thus finds a purpose to the playful antics of several comedians and other entertainers. It takes on "simplified notions of good and evil" and presents arguments counter to the discourse promoted by mainstream news media, the military-industrial complex and the Bush administration (Greene \& Gournelos 2011: xxvii). These essays analyse the political function served by cartoons and comedians and bring out an important shift in the political discourse of the United States. It is also an attempt to negotiate the media saturated political atmosphere and is as much a commentary on the news media as it is on the political establishment. The anthology grapples 
with politics by positing humour, satire and irony as important frameworks through which one may analyse post-9/11 politics.

This paper agrees with the assertion Greene \& Gournelos (2011) make, namely that humour can provide a counter-narrative to the dominant and hegemonic narrative authorised by the government. While Greene \& Gournelos (2011) provide a largely synchronic analysis, this paper would like to look at humour over a period of time. It tries to study the process of how humour came to provide an alternate version of events and how political comedy evolved in post-9/11 American media. The framework of disaster humour, specifically the mapping of patterns pioneered by Ellis, has been used to derive an idea of how the use of comedy, irony and satire developed over time and to what political issues it responded. Further, an analysis of any resultant pattern would provide a picture of how humour approached the major issues of the time.

For this purpose, I would like to look at The Boondocks and Get Your War On from 11 September 2001 to 31 December 2003. In my analysis, I would also like to use The Daily Show and The Onion as contemporary secondary texts to illustrate my points.

This paper tries to bring out the political and cultural roles played by humour in the political sphere and is especially interested in how it provides avenues for social and political critique. Further, I would like to look at how The Boondocks and Get Your War On produce humour, and how they use the instruments of irony and satire to analyse contemporary political scenarios. This paper argues that The Boondocks and Get Your War On, along with humour in other media such as The Onion and The Daily Show, employ humour as resistance against the dominant and hegemonic discourse propagated through mainstream news media. I also argue that seeing these media through the framework of disaster humour enables us to study the evolution of humour as resistance. Further, analysing the patterns in which humour appeared in these media can help us understand how humour engaged with politics in post9/11 United States. Finally, this paper looks at how humour attempts to explain the dominant political philosophies of our time, in relation to post-9/11 politics and the War on Terror. By drawing on contemporary theoretical analysis of post-9/11 politics, I argue that humour promotes a nuanced, historical understanding of political events of our time.

\section{Patterns}

The waves in which humour evolved in the early weeks of the post-9/11 decade may be tabularised as follows:

\begin{tabular}{|c|l|l|}
\hline Wave number & \multicolumn{1}{|c|}{ Feature of the wave } & Dates of first appearance \\
\hline 1 & Critique of the media & 25 Sep. to 01 Oct. \\
\hline 2 & Critique of jingoistic nationalist rhetoric & 01 Oct. to 02 Oct. \\
\hline 3 & $\begin{array}{l}\text { Critique of the role of Repressive State } \\
\text { Apparatus }\end{array}$ & 03 Oct. to 13 Oct. \\
\hline 4 & $\begin{array}{l}\text { Critique of the role of Ideological State } \\
\text { Apparatus }\end{array}$ & 15 Oct. to 23 Oct. \\
\hline
\end{tabular}

All the media surveyed in this study observed a moratorium on humour related to $9 / 11$. This was an expected phenomenon, observed by Ellis in his work, when society considered it to be "too soon" to start joking about a disaster fresh in the mind of the public. The silence was 
broken by The Boondocks in its strip on 25 September 2001, which commented on Mayor Giuliani's heroic posturing and the eager role the media played in facilitating it. From 25 September to 1 October, The Boondocks featured strips that critiqued the media's response to the terrorist attacks and its aftermath. On various days, it made reference to the corporate appropriation of the pathos and trauma of the tragedy, the sudden surge in feelings of nationalism and the bombastic nature of television news coverage that often appeared to be excessively dramatized and increasingly blood thirsty. A notable strip from this wave appeared on 27 September:

Caesar: Let's see. Channel 2 is "America's Vengeance", Channel 12 is "America at War" and Channel 33 is "America Strikes Back".

Huey: How about "America Stops and Thinks About Why Some People Hate Us?" Caesar: Doesn't quite lend itself to a John Williams style theme song, does it? (http://www.gocomics.com/boondocks/2001/09/27)

These strips constitute the first wave of post-9/11 humour and was characterised by a preliminary analyses of how the news media handled the political situation.

The commentary on how the media approached the tragedy gradually gave way to an inquiry into how the media was shaping public opinion and who was influencing the media's narrative of the events. Strips from 1 and 2 October satirises the blind nationalism and a pervading nationalistic rhetoric that became prevalent in the United States. While this wave initially appeared in The Boondocks only for two days, it would repeat itself for longer durations in later cycles, notably from 27 March to 7 April and 6 May to 4 July in the following year. These strips are a response to the war-mongering displayed in mainstream media immediately after 9/11. The strip from 2 October in particular recognised the same sentiments among the members of the government and comments upon the eagerness and speed in which the government decided that war was the answer to terrorist attacks. The second wave featured a deployment of humour to critique aggressive hyper-nationalism and war-mongering in the United States.

Get Your War On first appeared on 9 October. It began with a strip that chimed in with the second wave of humour featured on The Boondocks. The first strip of the series featured a parody of aggressive war-mongering attitudes and ridiculed the pro-war posturing of the Republican Party with lines such as:

Figure 1: Oh my God, this war on terrorism is gonna rule! I can't wait until the war is over and there's no more terrorism!

Figure 2: I know! Remember when the U.S had a drug problem, and then we declared a War on Drugs, and now you can't buy drugs anymore? It'll be just like that.

(http://www.mnftiu.cc/category/gywo/war1)

The second strip, dated 14 October, made jokes about aggressive nationalists who support the war and critiqued the role of the news media in creating an atmosphere of paranoia. On 30 October, Get Your War On came out with another strip that commented on the effects of the ideology of fear on common people in both Afghanistan and the United States.

The second wave soon metamorphosed into an examination of the new government policies and plans of action that were implemented as a reaction to 9/11. The Boondocks, from 3 to 13 October, focus on the increasingly powerful and pervasive role assumed by the FBI in 
post-9/11 America. The third wave of humour was an examination of procedures such as tapping the phones of civilians, profiling of Muslims and Arab Americans and a propaganda that spread fear of future terrorist attacks. Strips from 4 to 6 October also feature, Huey, the lead character of the cartoon, informing the FBI of America's geopolitical moves in previous decades that led to the emergence of terrorism. On 5 October, The Boondocks ran this strip:

Huey (on the phone to the FBI): Why do you keep hanging up on me? I'm telling the truth. The CIA trained Osama Bin Laden in using terrorism against the Soviets during the Reagan-Bush administration. They gave the Afghanistan rebels countless amounts of covert funding!

FBI: Don't you have better things to be doing?

Huey: Better than fighting terrorism? Heck no! We are at war!! (http://www.gocomics.com/boondocks/2001/10/05)

Get Your War On made only a brief reference to the scare tactics of the FBI, and moved on to caustic attacks on the Bush administration, the government machinery as well as various corporate and cultural institutions that supported the War on Terror. The weekly (and sometimes fortnightly) frequency of Get Your War On might be the reason why it did not give voice to the third wave. The increasing disillusionment with the War on Terror and the realisation that Afghanistan and the Taliban are not quite the cannon fodder they were thought to be was reflected in the strip that appeared on 8 November. The strip also invokes the economic downturn that the United States experienced at that point and comments on how the Bush administration was busy playing war games while the citizens of United States were being slowly impoverished. The strip goes on to further expose the role of religion in the global war on terror and questions the idea of fighting to "impress invisible superheroes who live in outer space" (http://www.mnftiu.cc/category/gywo/war6). Get Your War On portrays Bush as an autocratic leader in its 29 November strip and targets some of the ridiculous statements made by Bush, such as how he got a sense of Vladimir Putin's soul. Dick Cheney also comes in for severe criticism in this cartoon too and his invisibility to the public eye is pilloried.

Figure 1: George W. Bush is the man! The motherfucker can do anything he wants now! Good thing we know how much he hates incarcerating (and killing the fuck out of) his fellow Americans!

Figure 2: Wouldn't it be awesome if he granted himself supernatural powers in order to fight the evil-doers? "My fellow citizens - fuck the Constitution! I can now turn invisible at will!"

Figure 1: He already has the supernatural ability to look into Vladimir Putin's soul. (http://www.mnftiu.cc/category/gywo/war5)

The Boondocks too moved into this wave from 15 October to 6 November, with a detailed exposé on how the Bush administration had marshalled mainstream media and big corporations into aiding its War on Terror. The strips from this period satirise the effectiveness, or the lack of it, of the War on Terror and point to the heavy presence of the military industrial complex in post-9/11 politics. These strips also do not fail to mention how the administration continues to spread fear of imminent terrorist attacks if the government policies are not carried out in full effect. The strip from 23 October demonstrates how the 
government truly wants complete inaction and unquestioning allegiance from its citizens, when it says:

Narrator: After several weeks of terribly disturbing news with no end in sight, the Freeman clan, following twenty long minutes of quiet introspection at the front door, decided not start their day and returned to bed, thereby awarding a decisive victory to the terrorists. They will try again tomorrow. (http://www.gocomics.com/boondocks/2001/10/23)

The strips that ran from 24 to 27 October deserve special mention in that they make fun of the philosophy of the Bush administration that was being translated into foreign policy at that point in history. From thereon, the strip shifts its focus back to how the government uses tactics of fear and the repressive mechanism of the FBI to prevent criticism or public discourse that criticises the government policy. The fourth wave was a trenchant critique of the ideological state apparatus and how these organs colluded with the Bush administration to put out a particular version of history and current affairs.

These four waves constantly reappeared cyclically, at different times, in these cartoon strips until the early months of 2003. By then, the war on Iraq had become a distinct possibility and media attention shifted to the political discourse on Iraq and the presence of WMDs in that country. The topics of discussion on The Boondocks and Get Your War On also were narrowed down to Iraq, thus bringing an end to the cycle of disaster humour inspired by the terrorist attacks of September 11.

\section{Analysis of patterns}

The first target of irony and satire in post-9/11 America was the media and specifically concentrated on how mainstream news media reacted to the events of September 11. News is a fundamental aspect of public life and serves as the site of discourse in a democratic or democratising process. At the same time, it is also a product of power and claims the epistemic privilege of narrating events and makes truth claims about the nature of the society. As an instrument of power, it provides a platform to shape public perception and this place is occupied by those in power and those able to control the news media. Further, news often takes a top down approach and always seeks to hand down to the masses an authoritative version of what happens around the world. It is these characteristics of the news media which are countered using satire and irony.

In the aftermath of 9/11, news media in the United States accepted the Bush administration's version of events without scrutiny or suspicion. The characterisation of the attacks as 'Evil' which had suddenly and unfairly been inflicted upon the country was prevalent and most of mainstream media supported the government's reaction earnestly. Thus, it was left to humour and its applications to question and counter the government. One avenue of criticism often explored in humorous material is the exposition and examination of how politicians use media to their advantage. The Boondocks, for instance, does exactly that by looking at how Mayor Giuliani used the attacks as an opportunity to project himself into the national limelight. By having the news reporter accidentally refer to him as President Giuliani, the cartoon strip exposes the intention behind Giuliani's capture of the media. The Boondocks also seeks to satirise the bombastic nature of news coverage and compares it to a fictionalised entertainment production. By calling attention to the exaggerated headlines in 
news, such as "America's Vengeance" or "America Strikes Back", the cartoon strip tries to tell us how very like a film news has become. This was also the topic of satire for The Onion, when in their 26 September issue they ran the piece, "American Life Turns Into Bad Jerry Bruckheimer Movie".

The bombastic nature of television news has also been parodied by mocking the formalistic aspects of news broadcasts. The Daily Show is a parody of the news in such a manner, mimicking and exaggerating the dramatic music, its eye-catching but not always informative charts of statistics, graphics and accompanying captions and other aspects of news that makes it an entertainment package. This sustained exposure of the machinery of the news brings out the constructed nature of the news and lays bare the processes of narration, gate-keeping and agenda-setting practised by the mainstream news industry. As Bakhtin argues in his Rabelais and His World, laughter can serve as a form of resistance to power and is a way of confronting and deconstructing the discourse of authority (Bakhtin 1984: 10). By parodying the news and mocking the cinematic quality of the programming, The Boondocks and The Daily Show question the epistemic privilege of news and provide an alternate version of events that makes fun of the pronouncements of power.

In this process, parody provides an alternate discourse that is absent or denied to the viewers in "real" mainstream news. This is corroborated by the fact that comedians like Jon Stewart and Stephen Colbert are trusted "journalists" or news broadcasters in the United States. Studies have shown that viewers of talk shows hosted by these comedians also tend to be more politically aware than the general population. ${ }^{1}$ Thus, these critiques of the news, primarily through parody, achieve a levelling of the epistemological field. Parody becomes a means of talking back, or with, the discourse of authority peddled on mainstream news networks. Parody inhabits the discursive space that news usually occupies and mocks it by overly identifying with many of the formalistic aspects of it. In doing so, The Boondocks and The Daily Show break the traditional interpretive frames that mainstream news offers.

The second wave of humour saw the prevailing attitudes of jingoism and hypernationalism as knee-jerk reactions and tried to expose the contradictions and sometimes the absurdity in the dominant public attitude. The Onion, on 26 September, perhaps featured the best example of this with the headline, "Not Knowing What Else To Do, Woman Bakes American Flag Cake". Get Your War On perhaps best satirises the prevailing state of the discourse by imitating the aggressive posturing that accompanied post-9/11 America. This wave targets politicians and their philosophies, thus moving a step further in political criticism. In subjecting this war-mongering attitude to satire and irony, this cartoon series uses humour as a self-reflexive, self-aware tool that can confront or challenge the dominant discourse. This wave sought to reverse the hierarchy of the dominant discourse by deconstructing the philosophy behind it. Once again, The Onion captures the absurdity of the situation with the headline "U.S Vows to Defeat Whoever It Is We're at War With" (http://www.theonion.com/articles/us-vows-to-defeat-whoever-it-is-were-at-war-with,219/).

The dominant discourse maintains a hierarchy that sees the Bush administration as 'Good' and the rest as 'Evil'. The supporters of the 'Good' side are given a higher place in this hierarchy. Irony and sarcasm destabilise the narrative of 'Good' versus 'Evil' and therefore has a politically transformative power. Irony and sarcasm can thus be a counterdiscourse to the dominant one and can displace and annihilate the dominant depiction of the world. In the strips of Get Your War On, the statements and philosophy behind Republican posturing are re-contextualised to produce humour. By using the same language as the

1 http://www.people-press.org/2007/04/15/public-knowledge-of-current-affairs-little-changed-by-news-andinformation-revolutions/ 
dominant discourse, it seeks to deconstruct and destabilise this discourse and tries to appropriate its power.

Humour is often produced by exploiting the disjunction between the way things are supposed to be and the way they actually are. In the case of humour in post-9/11 United States, cartoons and television talk shows juxtapose the intentions or public proclamations with what is actually performed or made to happen. In keeping with Simon Critchley's argument in On Humour, media such as The Boondocks and Get Your War On puncture the American conception of daily reality. Humour is produced by defeating the expected turn of events and, in doing so, these media make us aware of the new reality around us (Critchley 2002: 1).

Bakhtin considered parody to be a coming together of two of his great interests carnival and dialogism. Bakhtin argued that readers do not make meaning out of a text in vacuum, but that texts are always understood relative to other texts. Thus, meaning has a social character and it is always in the process of becoming. Parody is a vehicle of Bakhtinian ideas because it tries to re-contextualise texts (Volosinov 1973: 27).

In this sense, The Boondocks and Get Your War On parody the news by repeatedly questioning the meaning of an ordinary news broadcast. The act of parody enables the viewer or the reader to experience those facets of the object that are not usually included in the dominant style of the text or genre. Thus, these media constantly force the meaning of news to be recast and reinterpreted and work against the atrophy of meaning.

Satire offers its audience a meaningful way of engaging with post-9/11 politics. By criticising the prevalent norm, humour enables its practitioners to stand outside the norm and achieve a de-familiarised stance towards it. As Bakhtin argues, humour prevents a norm from becoming entrenched and beyond criticism by encouraging people to tamper with it, take it apart and examine it (Bakhtin 1981:23). Thus, these media of humour serve as instruments of resistance against the dominant ideology and its norms. In post-9/11 United States, where the news media fully committed itself to the Bush administration's framing of events, laughter and humour became one of the few spaces where these ideological forces could be resisted and questioned.

Freud theorised that humour is an act of covert aggression towards institutions or people who held power (Freud 1960 [1905]: 117). For The Boondocks and Get Your War On, the mainstream news media is an instrument of government power, which spread fear and apprehension about the terrorist Other to maintain control over the population and push its specific ideological agenda. Laughing at the dominant discourse is a release of aggression and an act of putting down this institution which holds great power over its viewers.

The third wave features a critique of the repressive state apparatus and its application in post-9/11 United States. Specifically, it targets the new role and the expanded powers of the FBI. The strips from The Boondocks and Get Your War On deal with this issue in a theoretical framework of the FBI and other such organs as Repressive State Apparatuses, in a manner similar to the theory put forward by Althusser (1968: 139). The FBI assumed several pervasive powers, through legislation brought about by the Bush government such as the USA PATRIOT Act of 2001. Passed in the aftermath of 9/11, this law empowered the FBI to tap telephone and e-mail services, search homes without court orders and provided for indefinite detention of illegal immigrants.

The application of satire and irony exposes the role the FBI plays to preserve and reinforce the dominant, ruling ideology. The Boondocks reveals the role the FBI plays in maintaining the imperialistic foreign policy of the United States and argues that the new powers granted to the bureau are a means of curbing domestic dissent against the ideology of 
the Bush administration. In its strips, The Boondocks inverts the new role of the FBI by informing the bureau of previous American governments who helped the Taliban grow into a major political force. Thus, the cartoon questions the use of the FBI by the government, while also critiquing the larger policy outlook of the Bush administration.

Through this approach, The Boondocks urges its readers to gain a perspective on history and study the origins of terrorism as a part of America's geopolitical moves during the last decades of the twentieth century. It also recontextualises the practices of the FBI and the government by placing the blame for global terrorism at their door step. Over repeated cycles, the cartoon has taken this approach while commenting on the FBI. This wave also comments on the racist and Islamophobic nature of many of the operations of the FBI and offers a critique of the divisive nature of post-9/11 politics. It also calls to attention the philosophy or world view that underlies the policies of the Bush administration, in which the world is divided into "Good" and "Evil", with White, Christian America and its allies constituting the former category.

This wave is evidently still caught up in trying to achieve closure of a certain kind by trying to find a definitive cause behind the terrorist attacks of September 11. In a way, the cartoon is still addressing the question of "why do they hate us?". However, The Boondocks and its political leanings do not allow a jingoistic outburst or aggressive war-mongering. Rather, it promotes a nuanced historical understanding of events. In doing so, The Boondocks sends out a clear political message that suggests that America needs to look inwards to realise the answer to that question.

The fourth wave of humour dealt with the response of the cultural institutions and corporations to post-9/11 politics and how they inculcated or resisted the government version of events. These institutions, which Althusser called Ideological State Apparatuses, are spread across the domains of religion, education, corporations, media and law, to mention a few. Althusser (1968: 142) argues that it is impossible for a State to hold power without propagating its ideology through various Ideological State Apparatuses and maintaining a hegemony across society. In the fourth wave, The Boondocks looks at how the dominant political discourse in the United States, propagated through media, and acted upon by educational institutions, religious institutions and corporations, is restricted to the fear of future terrorist attacks and a pervasive acceptance of war. The Boondocks begins its strips in this wave by questioning the collusion of the media and the government and the atmosphere of fear it generated all across the country. The strips then go on to expose the role of corporations in the War on Terror and lay bare the military-industrial complex that is involved in the operations put forward by the Bush administration.

The nature of the political discourse in the United States is the major target of satire and irony in The Boondocks and Get Your War On. These cartoons rebel against the boundaries of the mainstream political discourse and critique the Ideological State Apparatuses for refusing to move beyond the margins defined by the Bush administration. Further, these cartoons take it upon themselves to redefine the discourse and focus on topics that are not covered in the mainstream discourse. It should not be forgotten that irony or satire by themselves do not favour a political ideology, but they are merely deployed to serve the interests of one ideological camp by creative cartoonists and comedians. The use of satire and irony to talk about political issues is very effective in consolidating a political community and it gives an entertaining voice to a discursive community, especially when it has been marginalised in mainstream news media that has traditionally seen humour as not serious.

Irony is the mode of the unsaid and very often an expression of the power of language to mean something beyond what is contained in the literal meaning of words. Irony enables 
the speaker to express a certain attitude towards the topic, through what is said and unsaid. At the same time, the interpreter or the audience also constructs meaning in what the ironist has said and forms an evaluative attitude towards the topic (Hutcheon 1994: 10). Irony lies in the grey area between the said and the unsaid; it is a liminal phenomenon and exists in semantic meaning as well as in the attitude conveyed. However, irony is not achieved by merely inverting what is said. Rather, it happens in the space between and needs both the said and the unsaid to create that effect.

A good example of irony inhabiting this liminal space is the cartoon series Get Your War On. This cartoon features scathing satire of aggressive pro-war propaganda, which is achieved by an-over-the-top representation that becomes a mockery of what is portrayed. In Get Your War On, the characters are often hyper-masculine, jubilantly pro-war and revel in war-mongering and celebrating the imminent triumph of the philosophy of the Bush administration. It is hard to believe that actual people might talk in this manner, but the lack of believability of the dialogues only heightens the sense of irony and aids in ridiculing the policies of the Bush administration under the banner of War on Terror. It also showcases a perverse pleasure that adherents of the administration are alleged to enjoy through enacting such policies. The irony in Get Your War On does not lie simply in the semantic opposite of the dialogues. Rather, the dialogues and the way they are put convey a certain attitude towards the topic. This attitude is definitely evaluative in nature and thus indicates a political position with regard to the issues being discussed in the cartoon. The cartoon satirises the entire discourse on war and mocks the effectiveness of war by overly identifying with its proponents. Thus, Get Your War On uses satire to create a discursive space that was unavailable in the mainstream news media to critique the War on Terror and its many endeavours.

The challenge for media such as Get Your War On is to confront a discourse that excludes opinion that lies outside a very narrow political spectrum. It has to operate on the social plane as well as the mental, on the public axis as well as on the covert one. Thus, it has to engage with government's framing of the events of $9 / 11$, but manages to do so while keeping a critical distance from it, and thus questioning and undermining it. The complexity and multivocality that the cartoon brings challenges the rigid, narrow discourse that refuses to include voices that call for solutions other than war. What irony achieves in Get Your War On is similar to what African-American theorists such as Mitchell-Kernan (1973: 311) have called "signifying". Here, irony is a rhetorical strategy and even a political method that deconstructs and decentres hegemonic discourses.

In Get Your War On, the clever use of irony also brings in an atmosphere of ambiguity, which rubs off on the topics discussed in the strips. The cartoon encourages multiple voices within its text and invites readers to make their own conclusions. There is an ambiguity about the intention of the author, David Rees, in writing such dialogue. The literal meaning of the lines, along with the obvious sarcastic and ironic tone of the cartoon creates an ambiguity of meaning. While the written word remains, irony is always biased in favour of the unsaid. This creates an ambiguity between the literal meaning and the ironic meaning. The ambiguity of these strips questions the certainty and centrality of American power and questions the way in which it is wielded.

The waves of humour on post-9/11 politics reveal the political thinking that characterised the post-9/11 discourse in the United States. As some of the major voices that questioned the Bush administration and the War on Terror, these media deconstructed the political philosophy of the government and in the process also put forward philosophical arguments of their own. 
The main strand of criticism that characterised The Boondocks and Get Your War On was an emphasis on America's past support to its current enemies and a call to examine how previous governments fostered these forces. Accordingly, these texts encourage their audience to dwell on the history of America's support for the Taliban and Saddam Hussein, when they were seen as allies in the Cold War. But these forces are seen as an excess to the global capitalistic order of today and hence need to be removed as soon as possible. These forces are not the remainders of the past, but products of modernity and global capitalism. They have over-identified with the power of military, become an instrument of capitalistic Power and finally, a radical excess. Osama bin Laden and Saddam Hussein represent the obscene underbelly of global capitalism and whenever they come into public view, they have to be eliminated.

The Bush administration framed the post-9/11 political scenario as a conflict between "Good" and "Evil". The texts under discussion here unanimously opposed such a characterisation and sought to reframe the events. The mainstream political discourse veered too close to Huntington's idea of a clash of civilisations, which coalesced with the Bush administration's narrative that the White, Christian, Western civilisation constituted the "Good", while their targets made up the Axis of Evil. However, The Boondocks and Get Your War On prefer to see the contemporary conflict as a clash within civilisations. They comment on the faceless and remote nature of the war and also accept that, in addition to the conventional machinery of the military, organisations such as the World Bank or IMF and multinational corporations also play a significant role. International terrorism is the obscene underbelly of this global system of capitalism. The United States, which sit at the apex of this system, are passive nihilists, as Nietzsche would say, while the terrorists are active nihilists. These texts prefer a historical and materialistic explanation of the phenomenon of terrorism over the one propagated by the Bush administration.

The United States used the events of September 11 to revert back to the fundamentals of its ruling ideology instead of critically examining its place in the world. This aspect of the post-9/11 discourse comes in for stringent criticism in these texts. Further, these texts also object to the nationwide perception that America is the innocent victim of evil terrorist conspiracies. Rather, these texts opt to see both the United States and terrorist organisations as parts of one totality and products of global capitalism. Thus, these texts invoke Hegel's dictum that evil resides in the very gaze that perceives evil all around itself and exhorts America to redirect its gaze inwards.

The Boondocks in particular decries post-9/11 American domestic and foreign policy as a reversal back to its own fundamentalist ideas of nation and national identity. It sees a resurgence of belief and conviction in an imperialist world view that sees terror attacks in isolation and as wanton acts of destruction. McGruder's strips exhibit a dark humour that papers over disappointment and anger at the Bush government for having missed an opportunity to introspect about its position in the world. The terror attacks were instead used as a device to strengthen the ideological commitment to a new (and old) imperialism and to quell voices of dissent that questioned these motives or advocated a responsibility to the rest of the world. While the dominant discourse answered the question of "why did this happen to us?" by painting "them" as "Evil", The Boondocks provides an alternate answer. It tells us that this happened to "us", "here", because the same had been happening to "them", "there". If events like these should not happen "here", they should not occur anywhere. These strips lament the fact that, instead of this recognition, the events of September 11 led to more aggressive threatening of the Other, a heady and dangerous mix of jingoism and paranoia that repeated the policies that led to the events of September 11. The Boondocks is especially 
belligerent to expose and deconstruct the American tendency to assume victimhood, which then became a justification for increasing its military might. Importantly, this cartoon does not justify Islamic terrorism, but sees it as a part of a totality which is co-constituted by America driven global capitalism.

Get Your War On sees the Republican rhetoric of imminent terrorist attacks on America as a fantasy of sublime nature, one that evokes terror and awe. The cartoon accuses pro-war sentiments of having its origin in a repressed level of the psyche that seeks to resist the immersion of the mind into the constructed reality that is our world. Here, the cartoon takes a Lacanian approach to the "Real" and reality. The Republican fantasy of further terror attacks stems from a desire to be a part of a violent and cataclysmic Real, which will tear the fabric of a banal, constructed reality (Zizek 2002: 6). It is a wait for an "absolute event", an Armageddon that will put an end to time. Get Your War On sees the war-mongering mainstream discourse as one that identifies with this fantasy and one that attains towards the realisation of a symbolic lack that reveals the limits of everyday life. This fantasy manifests itself as a spectacle or a fantastic event that would previously have been seen only in fictional accounts. The terrorist attack of 9/11 was one such event.

\section{Conclusion: Humour as resistance}

The post-9/11 decade has clearly demonstrated the role of humour as an instrument of resistance. Its practitioners have shaken away the shackles of being labelled "not serious enough" to become sought-after political commentators who command the audience of several millions. Comedy, satire and irony in the United States have shown how an intelligent discourse that critiques the rhetoric of aggressive nationalism and dichotomous views can be constructed even in mainstream media. The new discourse was characterised by several features, but in its ideological credentials, it is safe to say that humour in post-9/11 United States promoted a postmodern outlook on events. Humour is postmodern in character because it encourages doubt, chaos and relativism about the discourse it targets. Through its many manifestations, post-9/11 humour has portrayed America as a dystopian haven of unreason, where values continuously lose their validity.

These texts are excellent chronicles of the politics of the post-9/11 decade in the United States. They resist and react to the dominant discourse, while proposing their own political ideas and philosophies. In this regard, humour throws away the allegation that it is often incapable of constructing anything to replace the hypocrisies it debunks. While exposing and debunking hypocrisies should be valued in its own right, without a compulsion to provide an alternative, the additional endeavour of these comic artists deserves a special mention. The Boondocks and Get Your War On exhibit political leanings that would roughly align them with the Democratic Party. However, they are not shy to criticise that political faction too and remain loyal to the idea of a liberal, welfare state. With regard to the post-9/11 decade, these media repeatedly exhort their audience to look inwards and critically examine the position of the United States on the world stage. A historical understanding of world politics, as laid out by these texts, provides a fundamental answer to the American angst of why the terrorists targeted their country and what can be done in the future to resolve these issues.

\section{Primary sources}


McGruder, A. (2003). The Boondocks. [Comic strip]. www.gocomics.com/theboondocks (accessed 1 May 2014).

Rees, D. (2003). Get Your War On. [Comic strip]. www.mnftiu.cc/category/gywo (accessed 1 May 2014).

\section{References}

Althusser, L. (1971). 'Ideology and ideological state apparatuses', in Althusser, L., Lenin and Philosophy and Other Essays. Translated by Brewster, B., London \& New York: Verso, pp. 127-185.

Bakhtin, M. M. (1981). The Dialogic Imagination. Translated by Emerson, C. \& Holquist, M. Austin, Texas: University of Texas Press.

Bakhtin, M. M. (1984). Rabelais and his World. Translated by Iswolsky, H. Bloomington, IN: Indiana University Press.

Critchley, S. (2002). On humor. New York: Routledge.

Davies, C. (2003). 'Jokes that follow mass-nediated disasters in a global electronic age', in Narváez, P. (ed), Of Corpse: Death and Humor in Folklore and Popular Culture, Logan, Utah: Utah State University Press, pp. 15-34.

Ellis, B. (1991). 'The last thing... said: The Challenger disaster jokes and closure'. International Folklore Review 8, pp. 110-124.

Ellis, B. (2003). 'Making a big apple crumble: The role of humor in constructing a global response to disaster', in Narváez, P. (ed), Of corpse: Death and Humor in Folklore and Popular Culture. Logan, Utah: Utah State University Press, pp. 35-81.

Freud, S. (1960). Jokes and their Relation to the Unconscious. Translated by Strachey, J. London: Hogarth.

Gournelos, T. \& Greene, V. (2011). 'Introduction', in Gournelos, T. \& Greene, V. (eds.), A Decade of Dark Humor: How Comedy, Irony and Satire Shaped Post 9/11 America, Jackson, Mississippi: University of Mississippi Press, pp. xi-xxxv.

Hutcheon, L. (1994). 'Risky business: The transideological politics of irony', in Hutcheon, L., Irony's Edge: The Theory and Politics of Irony, London: Routledge, pp. 9-34.

Mitchell-Kernan, C. (1973). 'Signifying', in Dundes, A. (ed.), Mother Wit from the Laughing Barrel: Readings in the Interpretation of Afro-American Folklore, Englewood Hills, New Jersey: Prentice-Hall, pp. 310-329.

Oring, E. (1987). 'Jokes and the discourse on disaster'. The Journal of American Folklore 100 (397), pp. 276-286.

Volosinov, V. N. (1973). Marxism and the Philosophy of Language. Translated by Matejka, L. \& Titunik, I. R. London: Seminar.

Zizek, S. (2002). Welcome to the Desert of the Real: Five Essays on September 11 and Related Dates. London: Verso. 